\title{
AGGRESSION AND STATE RESPONSIBILITY AT THE INTERNATIONAL CRIMINAL COURT
}

\author{
MeAgan S. Wong*
}

\begin{abstract}
The definition of the crime of aggression in Article 8 bis of the Rome Statute of the International Criminal Court (Rome Statute) stipulates that a State act of aggression is a material element of the crime, suggesting an intrinsic link between individual criminal responsibility and State responsibility for aggression. This article argues that the Rome Statute provides a legal basis for the International Criminal Court (ICC) to determine State responsibility for aggression when considering the material elements of the crime of aggression, which has important practical and conceptual implications for the law of international responsibility. Although the content of State responsibility flows automatically from the breach of the obligation, it is argued that a finding of aggression pursuant to Article 8 bis of the Rome Statute may be considered as a form of satisfaction for the purposes of Article 37 of the 2001 ILC Articles on Responsibility of States for Internationally Wrongful Acts (2001 ILC Articles). Furthermore, the material element of the crime in Article 8 bis of the Rome Statute requires the act of aggression by its character, gravity, and scale to constitute a manifest violation of the Charter of the United Nations, in line with the nomenclature used within the 2001 ILC Articles regarding serious breaches of obligations arising from peremptory norms of general international law (jus cogens). The article considers the important role that the ICC may play in relation to serious breaches of the jus cogens obligation to refrain from an act of aggression.
\end{abstract}

Keywords: public international law, aggression, crime of aggression, State responsibility, individual criminal responsibility, International Criminal Court, international dispute settlement, reparation, satisfaction.

\section{INTRODUCTION}

On 17 July 2018, two decades after the adoption of the Rome Statute of the International Criminal Court (Rome Statute), the International Criminal Court

* Lecturer in Law, University of Essex, meagan.wong@essex.ac.uk. I am grateful to Christiane Ahlborn, Antonio Coco, Olufemi Elias, Lawrence Hill-Cawthorne, Miles Jackson, Vladyslav Lanovoy, Noam Lubell, Martins Paparinskis, Felipe Viveros-Montoya, and Katja Ziegler for their comments on an earlier draft of this article; to the University of Bologna, the International Law Research Cluster at the University of Leicester Law School, and the Grotius Dialogue at Leiden University for the opportunity to present my work in progress; and finally, to the journal's anonymous peer reviewers for their comments. 
(ICC) activated its jurisdiction over the crime of aggression. This crime was defined in 2010 by the Assembly of States Parties to the Rome Statute (ASP) as including State conduct as a material element. ${ }^{1}$ Article 8 bis(1) of the Rome Statute stipulates that, for the purposes of the Statute:

'crime of aggression' means the planning, preparation, initiation or execution, by a person in a position effectively to exercise control over or to direct the political or military action of a State, of an act of aggression which, by its character, gravity and scale, constitutes a manifest violation of the Charter of the United Nations.

This definition interlinks the act of aggression and the crime of aggression in formal terms and suggests a conceptual connection between individual criminal responsibility for aggression and State responsibility. The ordinary meaning of the language seems to suggest that the Court is now competent to consider questions concerning State responsibility for aggression. This proposition may seem contrarian: the ICC is a judicial institution dealing with individual criminal responsibility, ${ }^{2}$ and State responsibility and individual criminal responsibility are conceptually and technically distinct legal regimes in international law. ${ }^{3}$ Alain Pellet, for example, thought it was clear that 'it is not the ICC's function to judge sovereign States'. ${ }^{4}$ Nevertheless, if the crime of aggression is prosecuted before the Court, the ICC will be required to consider State responsibility for an act of aggression.

This article argues that the Rome Statute does indeed provide a legal basis for the Court to determine State responsibility for aggression, which has two important practical and conceptual implications. First, the determination by the Court of an act of aggression pursuant to Article 8 bis of the Rome Statute may constitute a form of satisfaction, ${ }^{5}$ which is an extraordinary form of reparation applicable in the institutional setting of the ICC. Further, penal action against the individual or the adjudicative process itself may also be

1 The Assembly of States Parties to the Rome Statute of the International Criminal Court (ASP) adopted at the 13th plenary meeting on 11 June 2010 by consensus, Resolution RC/Res.6, which inserts a definition of the crime of aggression after Article 8 in Annex I. Prior to this meeting, Article 5(2) of the Rome Statute stipulated: 'The Court shall exercise jurisdiction over the crime of aggression once a provision is adopted in accordance with articles 121 and 123 defining the crime and setting out the conditions under which the Court shall exercise jurisdiction with respect to this crime. Such a provision shall be consistent with the relevant provisions of the Charter of the United Nations.' Note that Article 5(2) was deleted in accordance with RC/Res.6, Annex I of 11 June 2010 and is now referred to as 'former Article 5(2)' for the purposes of this paper.

${ }^{2}$ Rome Statute of the International Criminal Court (Rome Statute) Preamble, arts 1 and 25(1).

3 ILC, 'Draft Articles on Responsibility of States for Internationally Wrongful Acts' in Yearbook of the International Law Commission 2001 (United Nations 2001) vol II(2) 26 (2001 ILC Articles); Rome Statute (n 2) art 25(4). See P-M Dupuy, 'International Criminal Responsibility of the Individual and International Responsibility of the State' in A Cassese, P Gaeta and JRWD Jones (eds), The Rome Statute of the International Criminal Court: A Commentary (Oxford University Press 2002) vol II, 1060-1; R O'Keefe, International Criminal Law (Oxford University Press 2015) 79-81; see also T Ruys, 'Criminalizing Aggression: How the Future of the Law on the Use of Force Rests in the Hands of the ICC' (2018) 29 EJIL 887, 890.

${ }^{4}$ A Pellet, 'Response to Koh and Buchwald's Article: Don Quixote and Sancho Panza Tilt at Windmills' (2015) 109 AJIL 557, 562.

52001 ILC Articles (n 3) art 37. 
characterised as a form of satisfaction. ${ }^{6}$ Secondly, individual criminal responsibility at the ICC is premised on the aggravated regime of State responsibility arising from the act of aggression, ${ }^{7}$ as the State conduct element in the definition of the crime of aggression in Article 8 bis reflects the nomenclature found in the 2001 International Law Commission's Articles on responsibility of States for internationally wrongful acts (2001 ILC Articles) regarding a serious breach of an obligation arising from a peremptory norm of general international law (jus cogens). ${ }^{8}$

This article is structured in four parts. First, the article draws upon State conduct being a material element of the crime of aggression in the Rome Statute to explain how individual criminal responsibility is predicated upon State responsibility (Section II). Secondly, it will be argued that the Rome Statute gives powers to the ICC to determine State responsibility for aggression under Article $8 \mathrm{bis}$, and that the jurisdiction of the Court over the crime of aggression fulfils the need of State consent. Consideration is also given to the potential findings of internationally wrongful acts which the ICC may make during the course of judicial proceedings concerning the crime of aggression (Section III).

Thirdly, with regard to the content of international responsibility that flows from the breach of the international obligation, it is submitted that satisfaction is an appropriate form of reparation when addressing State responsibility for aggression. Article 8 bis(1) requires that a threshold be met with regard to the character, gravity and scale of the act of aggression, in line with the nomenclature in the 2001 ILC Articles on a serious breach of an obligation arising from a peremptory norm of international law. ${ }^{9}$ Hence, it is argued that the Rome Statute provides for an institutionalised response to a serious breach of a peremptory norm, with individual criminal responsibility operating as a further element of State responsibility within the meaning of Article 41(3) of the 2001 ILC Articles (Section IV).

Fourthly, the article examines how States entitled to make a claim in accordance with Articles 42 and 48 of the 2001 ILC Articles can use the structures of the ICC to invoke the responsibility of the aggressor State, exploring the bilateral and multilateral aspects of implementation. An additional multilateral dimension is provided by the role of the ICC and

${ }^{6}$ Armed Activities on the Territory of the Congo (DRC v Uganda) (Reparations owed by the Parties) Verbatim Record CR 2021/11 (28 April 2021 at 3 pm) 79, para 15(d) (Kakhozi on behalf of the DRC).

7 See M Spinedi, 'From One Codification to Another: Bilateralism and Multilateralism in the Genesis of the Codificaton of the Law of Treaties and the Law of State Responsibility' (2002) 13 EJIL 1099; E Wyler, 'From "State Crime" to Responsibility for "Serious Breaches of Obligations under Peremptory Norms of General International Law"' (2002) 13 EJIL 1147, 1150; P Klein, 'Responsibility for Serious Breaches of Obligations Deriving from Peremptory Norms of International Law and United Nations Law' (2002) 13 EJIL 1241, 1244; A Cassese, 'On Some Problematic Aspects of the Crime of Aggression' (2007) 20 LJIL 841, 845-56.

${ }^{8} 2001$ ILC Articles (n 3) art 40.

9 ibid arts 40 and 41. 
Security Council as organs of international organisations that can trigger the initiation of an investigation where the crime of aggression, arising from an act of aggression, may have occurred. A proprio motu investigation by the Office of the Prosecutor (OTP) or a referral by the Security Council may result in the international responsibility for aggression (both of the State and individual) being invoked. The mere existence of these institutionalised structures demonstrates the progressive development of the concept of further consequences of a serious breach of a peremptory norm, even before their application in practice.

While the crime of aggression at the ICC is not a new subject of enquiry, ${ }^{10}$ scholarly contributions have hitherto focused predominantly on issues relevant to individual criminal responsibility, ${ }^{11}$ or conditions for the Court's exercise of jurisdiction. ${ }^{12}$ The link between State responsibility and individual criminal responsibility for aggression, on which this article focuses, ${ }^{13}$ has received limited attention. ${ }^{14}$ It is important not to understate the extent to which this

${ }^{10} \mathrm{C}$ Kreß and L von Holtzendorff, 'The Kampala Compromise on the Crime of Aggression' (2010) 8 JICJ 1179; S Barriga and L Grover, 'A Historic Breakthrough on the Crime of Aggression' (2011) 105 AJIL 517; C McDougall, The Crime of Aggression under the Rome Statute of the International Criminal Court (Oxford University Press 2013); S Sayapin, The Crime of Aggression in International Criminal Law: Historical Development, Comparative Analysis and Present State (Springer 2014); P Grzebyk, Criminal Responsibility for the Crime of Aggression (Routledge 2015); G Kemp, Individual Criminal Liability for the International Crime of Aggression (2nd edn, Intersentia 2015).

${ }_{11}$ KJ Heller, 'Retreat from Nuremberg: The Leadership Requirement in the Crime of Aggression' (2007) 18 EJIL 477; M Milanovic, 'Aggression and Legality: Custom in Kampala' (2012) 10 JICJ 165.

12 RS Clark, 'Negotiations on the Rome Statute, 1995-98' in C Kreß and S Barriga (eds), The Crime of Aggression: A Commentary (Cambridge University Press 2016) vol I; A Zimmermann, 'Amending the Amendment Provisions of the Rome Statute: The Kampala Compromise on the Crime of Aggression and the Law of Treaties' (2012) 10 JICJ 209; S Barriga and N Blokker, 'Entry into Force and Conditions for the Exercise of Jurisdiction: Cross-Cutting Issues' in C Kreß and S Barriga (eds), The Crime of Aggression: A Commentary (Cambridge University Press 2016) vol I; N Blokker and S Barriga, 'Conditions for the Exercise of Jurisdiction Based on Security Council Referrals' in $\mathrm{C}$ Kreß and S Barriga (eds), The Crime of Aggression: A Commentary (Cambridge University Press 2016) vol I; S Barriga and N Blokker, 'Conditions for the Exercise of Jurisdiction Based on State Referrals and Proprio Motu Investigations' in C Kreß and S Barriga (eds), The Crime of Aggression: A Commentary (Cambridge University Press 2016) vol I.

${ }^{13}$ ILC, 'Draft Code of Crimes against the Peace and Security of Mankind' in Yearbook of the International Law Commission 1996 (United Nations 1996) vol II(2) 43, art 16, Commentary, para 4; see also Dupuy (n 3).

14 For example, Van Schaack acknowledges the intrinsic link between State and individual conduct for aggression but focuses on the issue of domestic prosecution, B Van Schaack, 'Par in Parem Imperium Non Habet: Complementarity and the Crime of Aggression' (2012) 10 JICJ 133, 149; and J Trahan writes that Article 8 bis 'makes clear that the crime cannot occur without the required state act of aggression' but does not expand on the State responsibility aspects, J Trahan, 'The Crime of Aggression and the International Criminal Court' in LN Sadat (ed), Seeking Accountability for the Unlawful Use of Force (Cambridge University Press 2018) 315. But note the brief discussion in D Akande and A Tzanakopoulos, 'The Crime of Aggression in the ICC and State Responsibility' (2017) 58 HarvIntlLJ 33, 34-35D; in relation to State consent, D Akande and A Tzanakopoulos, 'Treaty Law and ICC Jurisdiction over the Crime of Aggression' (2018) 29 EJIL 939, 959. 
claim goes against mainstream thinking that the ICC may only consider questions of individual criminal responsibility for crimes within its jurisdiction. ${ }^{15}$ By challenging the current consensus that the ICC is not a competent forum to consider State responsibility, this article sheds light on a significant development in international law: States Parties to the Rome Statute have conferred powers to the Court to address State conduct in relation to aggression.

Thus, the crime of aggression at the ICC extends beyond international criminal law. This has implications for States Parties to the Rome Statute (and non-States Parties) whose interests are engaged during judicial proceedings at the ICC concerning the crime of aggression, since the law of State responsibility is engaged when the crime is prosecuted. Further, the ICC can be seen as providing an institutionalised response to a serious breach of a peremptory norm, in line with the progressive development of the rules of State responsibility. ${ }^{16}$

\section{UNDERSTANDING THE STATE CONDUCT ELEMENT OF THE CRIME OF AGGRESSION}

The definition of the crime of aggression in the Rome Statute is peculiar in that it provides for an internationally wrongful act of a State to be an element of the crime. The first paragraph of Article 8 bis provides:

the planning, preparation, initiation or execution, by a person in a position effectively to exercise control over or to direct the political or military action of a State, of an act of aggression which, by its character, gravity and scale, constitutes a manifest violation of the Charter of the United Nations.

An 'act of aggression' is further defined in Article 8 bis(2) as 'the use of armed force by a State against the sovereignty, territorial integrity or political independence of another State, or in any other manner inconsistent with the Charter of the United Nations'. Two points follow from this. First, an act of aggression for the purposes of Article 8 bis is defined by reference to interState conduct. Secondly, an act of aggression in paragraph 2 must satisfy the threshold in paragraph 1 to qualify as a crime of aggression. Consequently, not every act of aggression will amount to a crime of aggression for the purposes of Article 8 bis(1). The third point is related to and follows from the prohibition of aggression being a peremptory norm of general international law (jus cogens) ${ }^{17}$

15 Situation in the State of Palestine (Prosecution Response to the Observations of Amici Curiae, Legal Representatives of Victims, and States) ICC-01/18 (30 April 2020) para 33; A Reisinger Coracini and P Wrange, 'The Specificity of the Crime of Aggression' in C Kreß and S Barriga (eds), The Crime of Aggression: A Commentary (Cambridge University Press 2016) vol I, 316; Akande and Tzanakopoulos, 'The Crime of Aggression in the ICC and State Responsibility' (n 14) 33.

162001 ILC Articles (n 3) art 41, Commentary 3.

17 ibid art 40, Commentary 4; ILC, 'Peremptory Norms of General International Law (Jus Cogens)' (29 May 2019) UN Doc A/CN.4/L.936, Annex (ILC Draft Conclusions on Peremptory Norms of General International Law (Jus Cogens) on first reading) Draft Conclusion 23; D Tladi, 
that has the character of an erga omnes obligation. ${ }^{18}$ Thus, the nature of the prohibition of aggression means that its breach involves multilateral dimensions of State responsibility, as discussed in Sections IV and V. ${ }^{19}$

The State conduct element of the crime is the act of aggression which, by its character, gravity and scale, constitutes a manifest violation of the Charter of the United Nations (UN Charter). ${ }^{20}$ The Court will therefore have to determine the existence of such an act of aggression before examining the conduct of the individual. ${ }^{21}$ This is its key difference from all other crimes within the jurisdiction of the ICC:22 individual criminal responsibility for other crimes is not predicated on a finding of internationally wrongful State conduct.

The definition of genocide does not make any reference to State involvement. ${ }^{23}$ With regard to the definition of crimes against humanity, the ICC may have to evaluate State policy ${ }^{24}$ because an " "attack directed against any civilian population", means a course of conduct involving the multiple commission of acts ... against any civilian population, pursuant to or in furtherance of a State or organizational policy to commit such attack'. ${ }^{25}$ However, such a finding can be made on the basis of 'organizational' policy, as an alternative to 'State' policy, a notable difference from the crime of aggression where internationally wrongful State conduct is an element of the crime. Further, organisational policy extends beyond 'State-like organizations', ${ }^{26}$ consequently 'organizations not linked to a State may, for

'Fourth Report on Peremptory Norms of General International Law (Jus Cogens)' (2019) UN Doc A/CN.4/727, paras 59-60, 62-8. See also International Law Association, 'Final Report on Aggression and the Use of Force' (2018) (ILA Report on aggression and the use of force) 27.

18 The ICJ named the outlawing of aggression as an example of an obligation erga omnes in the Barcelona Traction, Light and Power Company, Limited (Belgium v Spain) (Judgment) [1970] ICJ Rep 3, para 34; 2001 ILC Articles (n 3) art 48, Commentary 10.

19 Wyler (n 7) 1155-7. See also Spinedi (n 7); L-A Sicilianos, 'The Classification of Obligations and the Multilateral Dimension of the Relations of International Responsibility’ (2002) 13 EJIL 1127.

${ }^{20} \mathrm{C}$ Kreß, 'The State Conduct Element' in $\mathrm{C}$ Kreß and S Barriga (eds), The Crime of Aggression: A Commentary (Cambridge University Press 2016) vol I.

21 The International Military Tribunal in Nuremberg (IMT) first determined whether Germany had committed wars of aggression prior to assessing the criminal responsibility of the defendants; as reproduced in 'Judgment of the International Military Tribunal for the Trial of German Major War Criminals, Nuremberg, 30 September and 1 October 1946 (Reproduced)' (1947) 41 AJIL 172, 186221; see also C Greenwood, 'What the ICC Can Learn from the Jurisprudence of Other Tribunals' (2017) 58 Harvard International Law Online Journal 71, 71-2.

22 Rome Statute (n 2) art 5(1).

23 ibid art 6; see also Application of the Convention on the Prevention and Punishment of the Crime of Genocide (Bosnia and Herzegovina $v$ Serbia and Montenegro) (Judgment) [2007] ICJ Rep 43, paras 297, 413-5.

24 ILC, 'Draft Articles on Prevention and Punishment of Crimes against Humanity' in 'Report of the International Law Commission on the Work of Its Seventy-First Session' (2019) UN Doc A/74/ 10, 11, para 44 (Draft Articles on Prevention and Punishment of Crimes Against Humanity) art 2(1), Commentaries 28-33.

${ }^{25}$ Rome Statute (n 2) art 7(1).

26 Situation in the Republic of Kenya (Decision Pursuant to Article 15 of the Rome Statute on the Authorization of an Investigation into the Situation in the Republic of Kenya) ICC-01/09-19-Corr (31 March 2010) para 90; Prosecutor v Germain Katanga and Mathieu Ngudjolo Chui (Decision on the confirmation of charges) ICC-01/04-01/07 (30 September 2008) para 394; Prosecutor v William 
the purposes of the Statute, elaborate and carry out a policy to commit an attack against a civilian population' ${ }^{27}$ The Court may thus prosecute crimes against humanity in the absence of a State policy, ${ }^{28}$ or committed by non-State actors. ${ }^{29}$

As regards war crimes, Article 8(1) of the Rome Statute stipulates 'the Court shall have jurisdiction in respect of war crimes in particular when committed as part of a plan or policy or as part of a large-scale commission of such crimes'. The Pre-Trial Chamber in the Situation in the Democratic Republic of the Congo held that 'the statutory requirement of either large-scale commission or part of a policy is not absolute but qualified by the expression "in particular"". ${ }^{30}$ The Trial Chamber also explained in Prosecutor v Jean-Pierre Bemba Gombo that "the term "particular" makes it clear that the existence of a plan, policy or large-scale commission is not a prerequisite for the Court to exercise jurisdiction over war crimes but rather serves as a practical guideline for the Court'. ${ }^{31}$ Thus, the requirement in Article 8(1), as 'part of a plan or policy', is not essential for war crimes.

Article 8 of the Rome Statute refers to '[g]rave breaches of the Geneva Conventions of 12 August 1949';32 '[o]ther serious violations of the laws and customs applicable in international armed conflict, within the established framework of international law';33 and, in the case of a non-international armed conflict, 'serious violations of article 3 common to the four Geneva Conventions of 12 August $1949^{\prime} .{ }^{34}$ However, this definition refers to obligations arising from treaties and custom binding on individuals, not States. The Court, pursuant to Article 8, looks at the conduct of individuals who have acted in breach of an obligation to refrain from violations of international humanitarian law (treaties and custom) that are criminalised, and it does not assess the conduct of a State. Thus, if a State agent commits

Samoei Ruto, Henry Kiprono Kosgey and Joshua Arap Sang (Decision on the confirmation of charges pursuant to Article 61(7)(a) and (b) of the Rome Statute) ICC-01/09-01/11 (23 January 2012) para 185; Situation in the Republic of Côte d'Ivoire (Corrigendum to the Decision pursuant to Article 15 of the 1998 Rome Statute on the authorisation of an investigation into the situation in the Republic of Côte d'Ivoire) ICC-02/11 (15 November 2011) paras 45-6.

27 Situation in the Republic of Kenya (n 26) para 92.

28 Draft Articles on Prevention and Punishment of Crimes Against Humanity (n 24) art 3(1), para 5; see also art 2(2)(a), Commentaries 32-3.

29 Prosecutor $v$ Callixte Mbarushimana (Decision on the confirmation of charges) ICC-01/0401/10 (16 December 2011) para 2; Prosecutor v Bosco Ntaganda (Decision on the Prosecutor's application under Article 58) ICC-01/04-02/06 (13 July 2012) para 22. Draft Articles on Prevention and Punishment of Crimes Against Humanity (n 24) art 2(1), Commentary 33. cf art 8 bis(1) Rome Statute, which requires that the perpetrator has to be a person 'in a position effectively to exercise control over or to direct the political or military action of a State'.

30 Situation in the Democratic Republic of the Congo (Judgment on the Prosecutor's Appeal against the Decision of the Pre-Trial Chamber I entitled 'Decision on the Prosecutor's Application for Warrants of Arrest, Article 58') ICC-01/04 (13 July 2006) para 70.

31 Situation in the Central African Republic in the Case of the Prosecutor v Jean-Pierre Bemba Gombo (Decision Pursuant to Article 61(7)(a) and (b) of the Rome Statute on the Charges of the Prosecutor against Jean-Pierre Bemba Gombo) ICC-01/05-01/08 (15 June 2009) para 211.

32 Rome Statute (n 2) art 8(2)(a). $\quad 33$ ibid art 8(2)(b). 34 ibid art $8(2)(\mathrm{c})$. 
war crimes, the Court can only attribute conduct to the individual — and not the State. This is different from the crime of aggression, where a determination of an internationally wrongful act must be made pursuant to Article 8 bis of the Rome Statute.

It might be wondered whether such inquiries really are so different from a determination by the Court of an act of aggression in proceedings on the crime of aggression. ${ }^{35}$ In the properly legal sense, the answer is 'yes'. In determining whether there is a 'State policy' or 'a plan or policy' for crimes against humanity and war crimes respectively, whilst the Court may refer to factual findings which are a part of the context, this does not convert them into legal or material elements of the crime. Factual findings concerning a State's plan or policy in relation to crimes against humanity and war crimes may have implications for State responsibility, but they are not legal determinations by the Court concerning the commission of an internationally wrongful act. More importantly, holding an individual criminally responsible for crimes against humanity or war crimes does not require a formal legal finding of State responsibility. The crime of aggression, on the other hand, requires the Court to make an assessment of State conduct drawing upon the law on the use of force. ${ }^{36}$ Individual criminal responsibility for the crime of aggression is thus predicated upon State responsibility for aggression. It may seem contrarian to suggest that the ICC determines State responsibility for aggression. But this reflects the amended Rome Statute, the legal order of the ICC, and the nomenclature in the 2001 ILC Articles, as will be argued in the next section.

\section{THE ICC AND THE INTERNATIONALLY WRONGFUL ACT OF AGGRESSION}

When prosecuting the crime of aggression, the ICC will have to assess conduct of a State pursuant to Article 8 bis of the Rome Statute. This section will first examine the competence of the Court to determine State responsibility and its powers to do so under the Rome Statute. Next, the jurisdictional regime of the ICC over the crime of aggression will be examined to consider whether State consent to the exercise of jurisdiction is upheld during proceedings. The section concludes by examining Article 8 bis of the Rome Statute with respect to findings by the Court of internationally wrongful acts.

\footnotetext{
35 C Stahn, "The "End", the "Beginning of the End" or the "End of the Beginning"? Introducing Debates and Voices on the Definition of "Aggression"” (2010) 23 LJIL 875, 879.

36 ME O'Connell and M Niyazmatov, 'What Is Aggression? Comparing the Jus Ad Bellum and the ICC Statute' (2012) 10 JICJ 189; Kreß, 'The State Conduct Element' (n 20); D Akande and A Tzanakopoulos, 'The International Court of Justice and the Concept of Aggression' in C Kreß and S Barriga (eds), The Crime of Aggression: A Commentary (Cambridge University Press 2016) vol I, 214-15; Stahn (n 35) 879.
} 
A. The Competence of the ICC to Determine the Responsibility of a State for Internationally Wrongful Acts

The ICC is an international criminal court which exercises jurisdiction over persons for crimes within Article 5(1) of the Rome Statute. ${ }^{37}$ Is it also competent to determine State responsibility for aggression? Reisinger Coracini and Wrange suggest, inter alia, that the Court 'has no mandate to pronounce on the responsibility of a State'. ${ }^{38}$ This section will challenge that view, by reference to the requirements of Article 8 bis(1) of the Rome Statute.

The question of whether the ICC has competence to determine State responsibility regarding aggression has to be answered by reference to the Rome Statute. The starting point is that the ICC is an international organisation. As such, its competence is derived from the powers attributed to it by its Member States, ${ }^{39}$ found in the Rome Statute. ${ }^{40}$ Article 1 of the Rome Statute, which establishes the Court, provides inter alia that 'the jurisdiction and functioning of the Court shall be governed by the provisions of this Statute'. Article 5 stipulates that the Court has jurisdiction with respect to the crime of aggression, ${ }^{41}$ and Article 8 bis sets out the jurisdiction ratione materiae of the crime.

Pursuant to Article 8 bis, the ICC needs to make a determination that there has been an act of aggression prior to determining individual criminal responsibility. Some have labelled the determination of an act of aggression in this context as a 'mere preliminary question' 42 or an 'incidental' finding of State responsibility in the context of determining individual criminal responsibility. ${ }^{43}$ As discussed in Section II, such a reading is hard to square with the ordinary meaning of Article 8 bis of the Rome Statute, which strongly suggests that the ICC cannot determine the criminal responsibility of an individual without first establishing that an act of aggression has occurred. The determination of the internationally wrongful act is a necessary condition for determining the criminal responsibility of the defendant and thus cannot be a 'preliminary' or 'incidental' matter during the proceedings. Further, the

37 Rome Statute (n 2) art 1.

38 Reisinger Coracini and Wrange (n 15) 316; see also Akande and Tzanakopoulos, 'The Crime of Aggression in the ICC and State Responsibility' (n 14) 33-4.

39 F Martines, 'Legal Status and Powers of the Court' in A Cassese, P Gaeta and JRWD Jones (eds), The Rome Statute of the International Criminal Court (Oxford University Press 2002) vol I, 215; A Pellet, 'Applicable Law' in A Cassese, P Gaeta and JRWD Jones (eds), The Rome Statute of the International Criminal Court: A Commentary (Oxford University Press 2002) vol II, 1053-5; G Bitti, 'Article 21 and the Hierarchy of Sources of Law before the ICC' in C Stahn (ed), The Law and Practice of the International Criminal Court (Oxford University Press 2015) 411; see also HG Schermers and NM Blokker, International Institutional Law (6th edn, Brill Nijhoff 2018) 165-8.

${ }^{40}$ Legality of the Use by a State of Nuclear Weapons in Armed Conflict (Advisory Opinion) [1996] ICJ Rep 66, para 25; see also Schermers and Blokker (n 39) 756-7; D Sarooshi, International Organizations and Their Exercise of Sovereign Powers (Oxford University Press 2005) 18. $\quad{ }_{41}$ Rome Statute (n 2) art 5(d). $\quad{ }_{42}$ Reisinger Coracini and Wrange (n 15) 316.

43 Akande and Tzanakopoulos, 'The Crime of Aggression in the ICC and State Responsibility' (n 14) 34-5. 
determination of an act of aggression is not an ancillary or incidental matter in relation to jurisdiction but is, rather, part of the very subject matter on which the Court's jurisdiction is based, ${ }^{44}$ and thus falls within the Court's competence pursuant to Articles 5 and 8 bis of the Rome Statute. As an international judicial institution, the ICC has the power to decide its own jurisdiction, commonly referred to as Kompetenz-Kompetenz. ${ }^{45}$ Article 19(1) of the Rome Statute stipulates that ' $[\mathrm{t}]$ he Court shall satisfy itself that it has jurisdiction in any case brought before it', ${ }^{46}$ which 'denotes competence to deal with a criminal cause or matter under the Statute'. ${ }^{47}$ Therefore the Court, if it is satisfied that it has jurisdiction over the crime of aggression, also has the competence to determine an act of aggression, as this falls within the very subject matter of Article 8 bis(1) of the Rome Statute. ${ }^{48}$

From an international institutional law standpoint, former Article 5(2) of the Rome Statute provided the ASP with the mandate to define the crime of aggression as it deemed fit. ${ }^{49}$ The ASP, by adopting the amendments to the Rome Statute in Kampala, conferred powers upon the Court to make a legal determination of an act of aggression pursuant to Article 8 bis. ${ }^{50}$ Identical Articles 15 bis(9) and $15 \operatorname{ter}(4)$ confirm the competence of the ICC to do so: 'a determination of an act of aggression by an organ outside the Court shall be without prejudice to the Court's own findings under this Statute'. ${ }^{51}$

44 cf Chagos Marine Protected Area Arbitration (Mauritius v United Kingdom), PCA Case No 2011-03, Final Award (18 March 2015) paras 220-1.

45 For a recent authoritative restatement of the proposition, with extensive reference to judicial practice of various courts and tribunals, see Arbitration Between the Republic of Croatia and the Republic of Slovenia, PCA Case No 2012-04, Partial Award (30 June 2016) para 157 ('in the absence of agreement to the contrary, an arbitral or judicial tribunal has, under general international law, jurisdiction to determine its own jurisdiction') and further authorities at paras 148-56.

46 Situation in Uganda (Decision on the Prosecutor's Application that the Pre-Trial Chamber Disregard as irrelevant the Submission Filed by the Registry on 5 December 2005) ICC-02/0401/05 (9 March 2006) paras 22-3; Prosecutor $v$ Kony et al (Decision of Admissibility of the Case under Article 19(1) of the statute) ICC-02/04-01/05-377 (10 March 2009) para 45; Prosecutor v Bemba (Decision Pursuant to Article 61(7)(a) and (b) of the Rome Statute on the Charges of the Prosecutor Against Jean-Pierre Bemba Gombo) ICC-01/05-01/08-424 (15 June 2009) para 23.

47 Situation in the Democratic Republic of the Congo in the case of the Prosecutor $v$ Thomas Lubanga Dyilo (Jurisdiction on the Appeal of Mr Thomas Lubanga Dyilo against the Decision on the Defence Challenge to the Jurisdiction of the Court pursuant to article 19(2)(a) of the Statute of 3 October 2006) ICC-01/04-01/06 OA4 (14 December 2006) para 24.

48 See Situation in the State of Palestine (Prosecution Response to the Observations of Amici Curiae, Legal Representatives of Victims, and States) (n 15) para 33.

49 It should be particularly noted that the only caveat given to the ASP is that the provision on the crime of aggression shall be consistent with the United Nations Charter (UN Charter) pursuant to former art 5(2) of the Rome Statute (n 1); see also N Blokker, 'The Crime of Aggression and the United Nations Security Council' (2007) 20 LJIL 867.

50 But see Akande and Tzanakopoulos who submit ' $\mathrm{t}$ ] he jurisdiction of the ICC extends only to the determination of the criminal responsibility of individuals,' Akande and Tzanakopoulos, 'The Crime of Aggression in the ICC and State Responsibility' (n 14) 33.

51 Barriga and Blokker, 'Entry into Force and Conditions for the Exercise of Jurisdiction: CrossCutting Issues' (n 12) 638-40. For a criticism of arts 15 bis(9) and $15 \operatorname{ter}(4)$, see Pellet (n 4) 563. 
However, these powers are also limited by the nature of their conferral. Schermers and Blokker note that international organizations are only competent to act as far as the powers attributed to them permit, and ... they may not use these powers for purposes other than those for which the powers have been given'. ${ }^{52}$ Article 8 bis expressly confers powers to the ICC to determine an act of aggression; the Court can therefore only examine State conduct in accordance with this provision of the Rome Statute. ${ }^{53}$ Thus, States Parties have not provided the ICC with a general competence to determine State responsibility but have done so only in relation to the responsibility that arises from a finding of an act of aggression pursuant to Article 8 bis.

It might be objected that Article 25(4) of the Rome Statute provides that '[n]o provision in this Statute relating to individual criminal responsibility shall affect the responsibility of States under international law'. Does Article 25(4) preclude the ICC from determining State responsibility? The starting point, in accordance with Article 31(1) of the Vienna Convention on the Law of Treaties 1969 (VCLT), is the ordinary meaning of 'affect', which suggests that none of the provisions relating to individual criminal responsibility can have a material effect on State responsibility. ${ }^{54}$ Individual criminal responsibility, according to O'Keefe, is 'a function of the violation by an individual of an international legal obligation binding on him or her'. ${ }^{55}$ This is separate and distinct from the responsibility of a State for an internationally wrongful act, which arises when a State has acted in breach of its international obligations. ${ }^{56}$ State responsibility and individual criminal responsibility are distinct forms of international responsibility arising from the breach of conceptually separate and distinct rules under international law. Accordingly, a finding of State responsibility does not relieve an individual of criminal responsibility, and likewise, a finding of individual criminal responsibility does not absolve the State from international responsibility. Under international law, State responsibility is without prejudice to individual criminal responsibility. ${ }^{57}$ This 'duality of responsibility' was acknowledged as a 'constant feature of international law' by the International Court of Justice (ICJ) in the Application of the Convention on the prevention and punishment of the crime of genocide case with particular reference to Article 25(4) of the Rome Statute. ${ }^{58}$

The better reading of Article 25(4) is that it reflects the 'duality of responsibility', in the sense that a finding by the ICC of individual criminal

52 Schermers and Blokker (n 39) 168; see also Commentary to Article 4, W Schabas, The International Criminal Court: A Commentary on the Rome Statute (2nd edn, Oxford University Press 2016) 106.

53 Schermers and Blokker (n 39) 758-60; Sarooshi (n 40) 18-19.

54 Oxford English Dictionary: the meaning of 'affect': 'to have a material effect on; to make a material impression on; to influence, move, touch' <www.oed.com>. ${ }^{55}$ O'Keefe (n 3) 79.

562001 ILC Articles (n 3) art 58; see also O'Keefe, ibid 79-80; D Akande, 'The Jurisdiction of the International Criminal Court over Nationals of Non-Parties: Legal Basis and Limits' (2003) 3 JICJ 618, 636; Dupuy (n 3).

572001 ILC Articles (n 3) art 58, Commentary 3.

58 Bosnian Genocide case (n 23) para 173; see also Draft Articles on Prevention and Punishment of Crimes Against Humanity (n 24) art 3(1), Commentary 5. 
responsibility does not affect the international responsibility of a State: the State can still be internationally responsible if it has engaged in internationally wrongful conduct. Applying this general proposition to the crime of aggression at the ICC, a finding of individual criminal responsibility for the crime of aggression does not affect the international responsibility of the aggressor State. The aggressor State is still responsible under international law for the act of aggression even if a State official has been found criminally responsible. There is nothing in the text of Article 25(4) which precludes the Court from making a determination of State responsibility for aggression. In short, the competence of the ICC to make a determination of an act of aggression stems from Articles 5 and 8 bis of the Rome Statute, powers expressly attributed to it by the States Parties to the Rome Statute.

\section{B. The Jurisdiction of the ICC over the Crime of Aggression and State Consent}

Although the prosecution of an individual for the crime of aggression entails the exercise of jurisdiction by the ICC over a natural person, ${ }^{59}$ Article 8 bis(1) of the Rome Statute makes State conduct an element of the crime, that is, a legal finding that the alleged aggressor State has committed an act of aggression pursuant to Article 8 bis(2), which satisfies the threshold element in Article 8 bis(1). As a result, the prosecution of an individual for the crime of aggression necessarily entails determination of State conduct. This raises a question of consent of the alleged aggressor State to the exercise of such jurisdiction. ${ }^{60}$ Is there a nod towards the indispensable third party principle ${ }^{61}$ The not always consistent judicial practice on the topic has been conceptualised as reflecting either a 'jurisdictional principle that flows from consent and is aimed at protecting actors that are capable in principle to appear before the inter-State adjudicator, or a principle of admissibility that flows from concerns about due process of actors of various kinds, absent from various proceedings', ${ }^{62}$ with the implication that 'both versions have a role to play, depending on the character of the institution, its own conception of judicial function, and the type of legal issue presented'. ${ }^{63}$

An argument can be made that this principle is not applicable to the ICC since it is not an inter-State dispute settlement forum, and that States are not parties to the proceedings. ${ }^{64}$ However, an unusual tension arises because the Court has to

59 Rome Statute (n 2) art 25(1).

${ }^{60}$ Monetary Gold removed from Rome in 1943 (Italy v France, UK and US) [1954] ICJ Rep 19, 33; Certain Questions of Mutual Assistance in Criminal Matters (Djiboutiv France) [2008] ICJ Rep 177, paras 60-2. See also D Akande, 'Prosecuting Aggression: The Consent Problem and the Role of the Security Council' (2010) Oxford Institute for Ethics, Law and Armed Conflict Working Paper $15-17$.

${ }^{61}$ M Paparinskis, 'Revisiting the Indispensable Third Party Principle' (2020) 1 Rivista di diritto internaziole 49.

62 ibid 53.

63 ibid.

${ }_{64}$ The Pre-Trial Chamber has taken the view that the Monetary Gold principle does not apply to the ICC in Situation in the State of Palestine (Decision on the Prosecution request pursuant to article 
consider the legality of State conduct when considering the crime of aggression pursuant to Article 8 bis. Leaving aside the question of the general applicability of the indispensable third party principle at the ICC in relation to future proceedings on the crime of aggression, the key question is whether the alleged aggressor State must consent to the Court's jurisdiction over the crime of aggression if it is not a party to the proceedings. This is because 'international judicial jurisdiction is based on and derives from the consent of States' and such consent could carry the legal significance of a waiver of the indispensable third party objection. ${ }^{65}$

Indeed, the question of the consent of the aggressor State was discussed by the States Parties during the negotiations leading to the adoption of the amendments to the Rome Statute on the crime of aggression ${ }^{66}$ and the conditions for the exercise of jurisdiction ultimately adopted by the ASP67 reflect the requirement of the consent of the alleged aggressor State to proceedings against an individual for the crime of aggression.

There are two jurisdictional regimes over the crime of aggression that may be 'triggered', depending on the circumstances in which the situation is referred to the Court. The first, under Article 15 bis, is triggered by State referrals or proprio motu investigations by the Prosecutor. ${ }^{68}$ The second, pursuant to Article 15 ter, is triggered by Security Council referrals. Although these trigger mechanisms are procedural in nature, the scope of the jurisdiction that the Court may exercise over the crime of aggression is based on the manner in which it is triggered. ${ }^{69}$ Hence, two separate jurisdictions over the crime of aggression exist, depending on whether jurisdiction was triggered by a State referral or proprio motu investigations, ${ }^{70}$ or by a Security Council referral. ${ }^{71}$

One of the key differences is that for State referrals and proprio motu investigations, Article 15 bis(5) stipulates:

In respect of a State that is not a party to this Statute, the Court shall not exercise its jurisdiction over the crime of aggression when committed by that State's nationals or on its territory. ${ }^{72}$

Thus, in the absence of a Security Council referral, the ICC may only exercise jurisdiction over the crime of aggression if both nationality and territorial

19(3) for a ruling on the Court's territorial jurisdiction in Palestine) ICC-01/18 (5 February 2021) para 59, fn 228.

${ }^{65}$ H Thirlway, 'The Law and Procedure of the International Court of Justice 1960-1989: Part Nine' (1998) 69 BYBIL 1, 4. On waiver, see J Crawford, State Responsibility: The General Part (Cambridge University Press 2013) 668.

66 As noted by the President of the Review Conference, Christian Wenaweser, one of the big questions leading up to the negotiations was 'whether some form of expressed consent by the alleged aggressor State should be required or not', C Wenaweser, 'Reaching the Kampala Compromise on Aggression: The Chair's Perspective' (2010) 23 LJIL 883, 884.
67 See (n 1) above.
69 See O'Keefe (n 3) 539.
68 Rome Statute (n 2) arts 13(a) and (c); art 15 bis(1).
70 Rome Statute (n 2) art 15 bis. 71 ibid art 15 ter.

72 ibid 15 bis $(5)$. 
principles of jurisdiction are met. ${ }^{73}$ In other words, the ICC can only investigate an individual who is a national of a State Party for the crime of aggression arising from an act of aggression committed on the territory of another State Party. Nationals from non-States Parties and aggression committed on their territory are excluded from the jurisdiction of the Court over the crime of aggression on the basis of State referrals and proprio motu investigations. Indeed, this differs from the jurisdiction of the ICC in relation to the other crimes in Article 5 of the Rome Statute, over which, pursuant to Article 12(2) (b), the Court may exercise jurisdiction so long as the alleged crime was committed on the territory of a State Party or by a national of a State Party. Accordingly, if either the nationality or territorial jurisdictional principle is fulfilled $^{74}$ the Court may exercise jurisdiction over genocide, crimes against humanity or war crimes.

The underlying rationale for the sui generis regime over the crime of aggression is the need for consent of the alleged aggressor State whose conduct will be considered in accordance with Article 8 bis. ${ }^{75}$ The alleged aggressor State must be a party to the Rome Statute, signifying its consent to the Court's jurisdiction pursuant to Article 12(1). As Security Council referrals are made under Chapter VII of the UN Charter, the consent of member States can be found in Article 25 of the UN Charter by which they 'agree to accept and carry out the decisions of the Security Council in accordance with the present Charter'. ${ }^{76}$ Through this provision in the UN Charter, all States, including those not Parties to the Rome Statute, consent to the Security Council referring its nationals or a crime allegedly committed on its territory to the ICC. ${ }^{77}$ Accordingly, pursuant to Article 15 ter, the ICC can exercise jurisdiction over the crime of aggression arising from an act of aggression committed by any State, including non-States Parties. ${ }^{78}$ Importantly, this means that the Court may only investigate and prosecute a national from a non-State Party and determine whether an act of aggression has been committed by a non-State Party if there has been a Security Council referral.

\footnotetext{
73 Japan, in particular, has been critical. Statement by Japan, in 'Statements by States Parties in explanation of position before the adoption of resolution $\mathrm{RC} / \mathrm{Res} .6$, on the crime of aggression' (2010) Review Conference official records, ICC Doc RC/11, Annex VII.

${ }^{74} \mathrm{H}-\mathrm{P}$ Kaul, 'Preconditions to the Exercise of Jurisdiction' in A Cassese, P Gaeta and JRWD Jones (eds), The Rome Statute of the International Criminal Court: A Commentary (Oxford University Press 2002) vol II, 607-9; see also Akande, 'The Jurisdiction of the International Criminal Court over Nationals of Non-Parties: Legal Basis and Limits’ (n 56) 618-19.

75 For a background to the negotiation history of the Kampala Amendments in relation to State consent, see Wenaweser (n 66) 884-5; Kreß and von Holtzendorff (n 10) 1212-16; N Blokker and C Kreß, 'A Consensus Agreement on the Crime of Aggression: Impressions from Kampala' (2010) 23 LJIL 889, 893; Barriga and Grover (n 10) 523-6. $\quad{ }^{76}$ UN Charter art 25.

77 See D Akande, 'The Legal Nature of Security Council Referrals to the ICC and Its Impact on Al Bashir's Immunities' (2009) 7 JICJ 333, 343.

78 Understanding 2 of the Kampala Amendments; see also Blokker and Barriga, 'Conditions for the Exercise of Jurisdiction Based on Security Council Referrals' (n 12) 648.
} 
In the absence of a Security Council referral, the ICC is precluded by Article $15 \operatorname{bis}(5)$ from exercising its jurisdiction over the crime of aggression when allegedly committed by a national of, or on the territory of, a non-State Party. There is, however, another layer of debate concerning the consent of the alleged aggressor State and the jurisdiction of the ICC in the event of State referrals and proprio motu investigations. This concerns whether the alleged aggressor State (Party) must ratify or accept the amendments on the crime of aggression - or if it is sufficient for the State Party which alleges that there has been an act of aggression to have done so. This goes to the manner in which States Parties express consent, with broadly two positions: either consent is expressed by way of the ratification or acceptance of the amendments to the Rome Statute on the crime of aggression, ${ }^{79}$ or it is implied by tacit consent, ${ }^{80}$ subject to the opt-out clause in Article 15 bis(4). ${ }^{81}$ The former suggests that consent is expressed by way of acceptance or ratification of the amendments to the Rome Statute, while the latter suggests that States Parties are deemed to have consented to the jurisdiction of the ICC over the crimes in Article 5 by being parties to the Rome Statute unless they opt out pursuant to Article 15 bis(4).

In 2017, the ASP adopted by consensus a Resolution for the Activation of the jurisdiction of the Court over the crime of aggression (Activation Decision), ${ }^{82}$ confirming that:

in the case of a State referral or proprio motu investigation the Court shall not exercise its jurisdiction regarding a crime of aggression when committed by a national or on the territory of a State Party that has not ratified or accepted these amendments. ${ }^{83}$

The legal effect of the Activation Decision as an authentic means of interpretation of the Rome Statute is not entirely clear. ${ }^{84}$ A question arises whether, under Article 31(3)(a) of the VCLT, the Activation Decision is a subsequent agreement between the parties regarding the interpretation of the Rome Statute. ${ }^{85}$ It is for the interpreter, ie the Court, to give appropriate

79 For example, Zimmermann, 'Amending the Amendment Provisions of the Rome Statute: The Kampala Compromise on the Crime of Aggression and the Law of Treaties' (n 12) 219-20; Akande and Tzanakopoulos, 'Treaty Law and ICC Jurisdiction over the Crime of Aggression' (n 14) 94953.

80 Rome Statute (n 2) art 12(1).

${ }^{81}$ Kreß and von Holtzendorff(n 10) 1212-16; Blokker and Barriga, 'Conditions for the Exercise of Jurisdiction Based on Security Council Referrals' (n 12) 664-8. See also M Fitzmaurice, 'Consent to Be Bound - Anything New under the Sun?' (2005) 74 NordJIntlL 483, 488-90.

82 Resolution ICC-ASP/16/Res.5, 'Activation of the jurisdiction of the Court over the crime of aggression' (Adopted at the 13th plenary meeting of the ASP to the Rome Statute, on 14 December 2017).

83 ibid para 2.

${ }^{84}$ See Akande and Tzanakopoulos, 'Treaty Law and ICC Jurisdiction over the Crime of Aggression' (n 14) 943-9; C Kreß, 'On the Activation of ICC Jurisdiction over the Crime of Aggression' (2018) 16 JICJ 1, 9-13; A Zimmermann, 'A Victory for International Rule of Law? Or: All's Well That Ends Well?: The 2017 ASP Decision to Amend the Kampala Amendment on the Crime of Aggression' (2018) 16 JICJ 19.

85 Akande and Tzanakopoulos, 'Treaty Law and ICC Jurisdiction over the Crime of Aggression' (n 14) 946-8. 
weight to the Activation Decision when interpreting the Rome Statute. ${ }^{86}$ That said, perhaps the better view is that the Activation Decision is a Rule of the Organization made by the ASP and, as such, prevails over the VCLT ${ }^{87}$ and is legally binding on organs of the ICC. ${ }^{88}$ Thus, the jurisdictional regime of the crime of aggression in the event of State referrals and proprio motu investigations can only be exercised upon ratification or acceptance by both the alleged aggressor and the alleged victim States Parties.

The counterargument is that the Court may disregard the Activation Decision, and exercise jurisdiction over the crime of aggression on the basis that the alleged aggressor State Party is deemed to have consented to the Court's jurisdiction provided it has not opted out pursuant to Article 15 bis (4). Accordingly, it would be sufficient to establish the Court's jurisdiction over this crime if the alleged victim State Party had ratified the amendments to the Rome Statute on the crime of aggression.

The details of the ICC's jurisdiction over the crime of aggression in the absence of a Security Council referral is outside the scope of this article. ${ }^{89}$ It suffices to note that in the absence of a Security Council referral, regardless of the interpretation ultimately to be applied by the ICC, the alleged aggressor State (Party) will have consented to the Court's exercise of jurisdiction either by ratification of the amendments to the Rome Statute on the crime of aggression, or by tacit consent (by not opting out), respectively. In the event of a Security Council referral, the alleged aggressor State is deemed to have consented as a consequence of Article 25 of the UN Charter. As a result, the principle of State consent is respected in the jurisdictional regime of the ICC over the crime of aggression. ${ }^{90}$ Accordingly, the indispensable third party principle, even if applicable, is addressed by the

86 ILC, 'Draft Conclusions on Subsequent Agreements and Subsequent Practice in Relation to the Interpretation of Treaties' (2018) UN Doc A/73/10, 12, para 51 (2018 ILC Draft Conclusions on Subsequent Agreements and Subsequent Practice) Draft Conclusion 11(3), Commentary 38.

87 MS Wong, 'The Activation of the International Criminal Court's Jurisdiction over the Crime of Aggression: International Institutional Law and Dispute Settlement Perspectives' (2020) 22 International Community Law Review 197; 2018 ILC Draft Conclusions on Subsequent Agreement and Subsequent Practice (n 86) Draft Conclusion 12(4); Draft Articles on Prevention and Punishment of Crimes Against Humanity (n 24) Draft Conclusion 12, Commentary 40.

88 Art 34 of the Rome Statute stipulates that Organs of the ICC are: (a) The Presidency; (b) An Appeals Division, a Trial Division and a Pre-Trial Division; (c) The Office of the Prosecutor; (d) The Registry.

${ }_{89}$ Akande and Tzanakopoulos, 'Treaty Law and ICC Jurisdiction over the Crime of Aggression' (n 14); Kreß, 'On the Activation of ICC Jurisdiction over the Crime of Aggression' (n 84); Zimmermann, 'A Victory for International Rule of Law? Or: All's Well That Ends Well?: The 2017 ASP Decision to Amend the Kampala Amendment on the Crime of Aggression' (n 84). See also Zimmermann, 'Amending the Amendment Provisions of the Rome Statute: The Kampala Compromise on the Crime of Aggression and the Law of Treaties' (n 12); Barriga and Blokker, 'Entry into Force and Conditions for the Exercise of Jurisdiction: Cross-Cutting Issues' (n 12); Barriga and Blokker, 'Conditions for the Exercise of Jurisdiction Based on State Referrals and Proprio Motu Investigations' (n 12).

${ }_{90} \mathrm{C}$ Kreß and L von Holtzendorff, 'The Kampala Compromise on the Crime of Aggression' (2010) 8 JICJ 1179, 1212-16. 
consent ${ }^{91}$ of the alleged aggressor State to the exercise of jurisdiction of the ICC over an individual for a crime of aggression arising from aggression it has allegedly committed. ${ }^{92}$

\section{Article 8 bis of the Rome Statute and the 2001 ILC Articles}

According to the 2001 ILC Articles, and reflecting customary international law, 'every internationally wrongful act of a State entails the international responsibility of that State'. ${ }^{93}$ Elements of an internationally wrongful act of a State pursuant to Article 2 of the 2001 ILC Articles comprise conduct consisting of an action or omission that (a) is attributable to the State under international law and (b) constitutes a breach of an international obligation of the State. ${ }^{94}$ A finding of an act of aggression pursuant to Article 8 bis of the Rome Statute would amount to a judicial determination of conduct attributable to the aggressor State that constitutes a breach of an international obligation of that State. A finding of an act of aggression by the ICC under Article 8 bis would be a legal determination of State conduct and thus a finding of an internationally wrongful act of aggression fulfils both necessary and sufficient criteria for establishing State responsibility.

As discussed in Section II, even if the threshold for the State conduct element set out in Article 8 bis(1) is not met, ${ }^{95}$ there will still have been a finding of an act of aggression under Article 8 bis(2). ${ }^{96}$ Similarly, if the ICC finds that the wrongdoing State has committed a violation of the prohibition of the use of force in Article 2(4) of the UN Charter or customary international law, ${ }^{97}$ rather than an act or crime of aggression itself, this finding would still constitute the determination that an internationally wrongful act had occurred. There are, therefore, three potential findings that the Court can

91 Conceptualised as a waiver, see Crawford, State Responsibility: The General Part (n 65) 668.

92 It is possible that even though the alleged aggressor and aggressed States are not considered to be indispensable third parties during proceedings on the crime of aggression, an issue of due process may nevertheless arise because the determination of the State conduct element of the crime would have an effect upon the legal rights and interests of the alleged aggressor State. This exceeds the present article but is nevertheless worth reflecting on-especially with an eye to future proceedings. See Chevron Corporation and Texaco Petroleum Company v Ecuador, PCA Case No 2009-23, Third Interim Award on Jurisdiction and Admissibility (27 February 2012) para 4.68-4.70. See also Paparinskis, 'Revisiting the Indispensable Third Party Principle' (n 61).

932001 ILC Articles (n 3) art 1; Advisory Opinion on the Legal Consequences of the Separation of the Chagos Archipelago from Mauritius in 1965 (Advisory Opinion) [2019] ICJ Rep 95, para 177.

942001 ILC Articles (n 3) art 2.

96 See Kreß, 'The State Conduct Element' (n 20) 435-53.

97 In the inter-State context, the ICJ has not made any determination of an act of aggression, even in the Armed Activities on the territory of the Congo case, regarding the dispute between the Democratic Republic of Congo (DRC) and Uganda concerning 'acts of armed aggression perpetrated by Uganda on the territory of the DRC', Armed Activities on the Territory of the Congo (DRC v Uganda) [2005] ICJ Rep 168, para 165. The decision to refrain from finding an act of aggression was criticised in the separate opinions of Judge Elaraby (paras 9-20) and Judge Simma (paras 2-3); see also Eritrea-Ethiopia Claims Commission-Partial Award: Jus Ad Bellum-Ethiopia's Claims 1-8 (2005) 26 RIAA 457-69. 
make which amount to a determination of internationally wrongful conduct: first, an act of aggression, which by its character, gravity and scale, constitutes a manifest violation of the UN Charter; secondly, an act of aggression; thirdly, a breach of the prohibition of the use of force under Article 2(4) of the UN Charter or customary international law. Each finding, regardless of the intensity of the breach of the international obligation to refrain from an act of aggression and inter-State force, entails the determination of State responsibility. 98

In that light, what, if any, are the legal implications of such a finding? The answer is provided by the customary law of State responsibility, according to which the content (remedial substance) of responsibility flows from the breach of an international obligation. ${ }^{99}$ New legal relationships therefore arise upon the commission by a State of an internationally wrongful act. ${ }^{100}$ The next section will consider the content of State responsibility that arises from an act of aggression and the manner in which this legal relationship is operationalised in ICC proceedings.

\section{CONTENT OF STATE RESPONSIBILITY FOR AN ACT OF AGGRESSION AS} DETERMINED BY THE ICC

Rules on the content of State responsibility ${ }^{101}$ address the new legal relationship that arises from the breach of an international obligation. Legal consequences for the internationally wrongful act of a State, according to Part Two of the 2001 ILC Articles, are, first, obligations to cease wrongful conduct; ${ }^{102}$ and secondly, to make full reparation for the injury caused by the internationally wrongful act. ${ }^{103}$ This section first focuses on the obligation of the aggressor State to make full reparation for the injury caused by the act of aggression, and considers the extent to which the ICC may play a role in the aggressor State discharging its obligation to make full reparation. As the prohibition of aggression is generally accepted to have the status of a peremptory norm, ${ }^{104}$ the section will then turn to the aggravated regime of State responsibility pursuant to Chapter III of Part Two of the 2001 ILC Articles and the role that the ICC may play in relation to Articles 40 and 41.

\section{A. Legal Consequences of an Internationally Wrongful Act}

The international responsibility of a State is entailed by an internationally wrongful act and involves legal consequences. ${ }^{105}$ These include an obligation

\footnotetext{
98 J Klabbers, 'Intervention, Armed Intervention, Armed Attack, Threat to Peace, Act of Aggression, and Threat or Use of Force: What's the Difference?' in M Weller (ed), The Oxford Handbook of the Use of Force in International Law (Oxford University Press 2015) 505.

992001 ILC Articles (n 3) Part Two. $\quad 100$ ibid Part Two, Commentary $1 . \quad 101$ ibid.

102 ibid art $30 . \quad 103$ ibid art 31, see Commentary.

104 ILC Draft Conclusions on Peremptory Norms of General International Law (Jus Cogens) on first reading (n 17) Draft Conclusion 23. 1052001 ILC Articles (n 3) art 28.
} 
to make 'full reparation for the injury caused by the internationally wrongful act', ${ }^{106}$ where 'injury includes any damage, whether material or moral, caused by the internationally wrongful act'. ${ }^{107}$ Importantly, the general obligation of reparation stems from the breach of the obligation itself. ${ }^{108}$ It is a new obligation, separate from the primary obligation that has been breached.

Thus, in the event of an act of aggression, the aggressor (responsible) State has an obligation to make full reparation for the injury caused by the internationally wrongful act, regardless of a formal finding by any international court or tribunal. ${ }^{109}$ Article 34 of the 2001 ILC Articles provides for several forms of reparation: '(f)ull reparation for the injury caused by the internationally wrongful act shall take the form of restitution, compensation and satisfaction, either singly or in combination, in accordance with the provisions of this chapter'. ${ }^{110}$

As the ICC is not a competent forum for inter-State disputes, the Court cannot order restitution or compensation for an act of aggression. This raises the question of satisfaction in such a case. Article 37(1) of the 2001 ILC Articles stipulates:

[t] he State responsible for an internationally wrongful act is under an obligation to give satisfaction for the injury caused by that act insofar as it cannot be made good by restitution or compensation. ${ }^{111}$

Under the law of State responsibility, satisfaction is one of the forms of reparation that allows a wrongdoing State to partially discharge its obligation to make reparation for the injury caused by the wrongful act. Since secondary rules of State responsibility are expressed without prejudice to institutions, it is entirely consistent with general rules to provide for particular forms of reparation to be addressed in a particular context, without prejudice to other forms of reparation that can be implemented in other judicial or non-judicial institutions or indeed in the usual informal manner. ${ }^{112}$ Furthermore,

106 ibid art 31(1), Commentary.

107 ibid art 31(2), Commentary.

108 The Permanent Court of International Justice held ' $[i] \mathrm{t}$ is a principle of international law that the breach of an engagement involves an obligation to make reparation in an adequate form' in Case Concerning the Factory at Chorzów (Germany v Poland) (Jurisdiction) [1927] PCIJ Rep Series A No 9, 21. See further 2001 ILC Articles (n 3) art 31, Commentary 4 ('The general obligation of reparation is ... the immediate corollary of a State's responsibility, i.e. as an obligation of the responsible State resulting from the breach, rather than as a right of an injured State or States.').

109 The ICJ has stated that "what constitutes "reparation in an adequate form" clearly varies depending upon the concrete circumstances surrounding each case and the precise nature and scope of the injury, since the question has to be examined from the viewpoint of what is the "reparation in an adequate form" that corresponds to the injury', Avena and other Mexican nationals Case (Mexico v US) [2004] ICJ Rep 12, para 119. See further Ahmadou Sadio Diallo (Guinea v DRC) (Compensation) [2012] ICJ Rep 324, paras 11-14; Certain Activities Carried Out by Nicaragua in the Border Area (Costa Rica v Nicaragua) (Compensation) [2018] ICJ Rep 15, para 30; Jadhav (India v Pakistan) [2019] ICJ Rep 418, para 138.

110 Certain Activities Carried Out by Nicaragua in the Border Area (n 109) paras 27, 31.

1112001 ILC Articles (n 3) art 37(1).

112 ibid art 37, Commentary 1 ('It is only in those cases where those two forms have not provided full reparation that satisfaction may be required.'). 
satisfaction is the appropriate remedy only for 'those injuries, not financially assessable, which amount to an affront to the State'. ${ }^{113}$ Forms of 'nonmaterial injury"114 would include "violations of sovereign and territorial integrity'. ${ }^{115}$ As aggression would also comprise non-material injury in addition to material injury, satisfaction would be an appropriate form of reparation for non-material injury in relation to an act of aggression. ${ }^{116}$

The ILC Commentary confirms that 'the forms of satisfaction listed in the article are no more than examples. ${ }^{117}$ Importantly, one example of satisfaction identified by the ILC in the Commentary to Article 37 is 'disciplinary or penal action against the individuals whose conduct caused the internationally wrongful act'. ${ }^{118}$ A determination of an act of aggression pursuant to Article 8 bis of the Rome Statute by the ICC might lead to potential penal action against an individual who planned, prepared, initiated or executed the act of aggression (provided the other elements of the crime pertaining to the individual have been met). ${ }^{119}$ In consequence, the prosecution of an individual for the crime of aggression may be considered a form of satisfaction for the act of aggression.

Another form of satisfaction noted by the ILC is a declaration of the wrongfulness of the act by a competent court or tribunal. ${ }^{120}$ This occurs

113 ibid art 37, Commentary 3 .

114 For the ubiquity of satisfaction as the remedy ordered and sought in international law, see Rainbow Warrior (New Zealand v France) (Arbitration Tribunal) (1990) 82 ILR 499, para 122 ('there is a long established practice of States and international Courts and Tribunals of using satisfaction as a remedy or form of reparation ... for the breach of an international obligation. This practice relates particularly to the case of moral or legal damage done directly to the State, especially as opposed to the case of damage to persons involving international responsibilities.').

115 ibid 271. See also Kreß, 'The State Conduct Element' (n 20) 419.

116 See Armed Activities on the Territory of the Congo (DRC v Uganda) (Reparations owed by the Parties) Memorial of the Democratic Republic of the Congo on the question of reparations (1 September 2016) paras 7.65-7.66.

${ }_{117} 2001$ ILC Articles (n 3) art 37, Commentary 5 ('the order of the modalities of satisfaction in paragraph 2 is not intended to reflect any hierarchy or preference. Paragraph 2 simply gives examples which are not listed in order of appropriateness or seriousness' and 'The forms of satisfaction listed in the article are no more than examples. The appropriate form of satisfaction will depend on the circumstances and cannot be prescribed in advance.').

1182001 ILC Articles (n 3) art 37, Commentary 5; see also the first reading, ILC, 'Draft Articles on State Responsibility' in Yearbook of the International Law Commission 1996 (United Nations 1996) vol II(2) 58, art 45(2)(d) ('Satisfaction may take the form of ... : in cases where the internationally wrongful act arose from the serious misconduct of officials or from criminal conduct of officials or private parties, disciplinary action against, or punishment of, those responsible'), Commentary 14 ('This mode of satisfaction is emphasized in literature and has frequently been requested and granted in diplomatic practice in the form of ... the setting up of a commission of inquiry and the punishment of the responsible individuals'); and J Crawford, 'Third Report on State Responsibility' (15 March, 15 June, 10 and 18 July and 4 August 2000) UN Doc A/ CN.4/507, para 192. In the pending Myanmar Genocide case, the Gambia has requested the Court to declare that Myanmar 'must ensure that persons committing genocide are punished by a competent tribunal', Application of the Convention on the Prevention and punishment of the crime of genocide (the Gambia v Myanmar) (Order of 23 January 2020) [2020] ICJ Rep 3, para 2.

119 Rome Statute (n 2) art 8 bis(1).

1202001 ILC Articles (n 3) art 37, Commentary 5 ('a judicial declaration is not listed in paragraph 2 only because it must emanate from a competent third party with jurisdiction over a dispute, and the articles are not concerned to specify such party or to deal with issues of judicial jurisdiction'). See 
when an international court or tribunal makes a finding that a State has acted in breach of an international obligation. ${ }^{121}$ With regard to a finding of the use of force, the classic example is the ICJ's declaration in the Corfu Channel Case that 'the action of the British Navy constituted a violation of Albanian sovereignty ... and [that the declaration] is in itself appropriate satisfaction'. ${ }^{122}$ More recently, the Guyana $v$ Suriname tribunal ruled that Surinamese naval actions constituted a threat of the use of force, contrary to international law and found that 'reparation in the form of satisfaction may be provided by a judicial declaration that there has been a violation of a right' or an obligation. ${ }^{123}$ By implication, the ICJ took a similar approach in Certain Activities Carried out by Nicaragua in the Border Area and Construction of a Road in Costa Rica along the San Juan River. ${ }^{124}$

Can a determination of aggression pursuant to Article 8 bis(1) and (or) Article 8 bis(2) of the Rome Statute be considered as a declaration of wrongfulness in the same manner as a finding of an internationally wrongful act in an inter-State forum? There is no need for the ICC to describe a finding of an act of aggression as a declaration of wrongfulness for it to be considered as a form of satisfaction. Indeed, satisfaction can take many forms, which 'cannot be prescribed in advance'. ${ }^{125}$ Thus, a factual or legal finding of an act of aggression pursuant to Article 8 bis may amount to a form of satisfaction, irrespective of whether such a finding by the ICC is couched in the language of a declaration of wrongfulness. The determination of aggression by the Court is a formal finding pursuant to Article 8 bis and, as argued above, States have consented to this.

A determination of an act of aggression by the ICC can be a form of satisfaction even though the judgment is not res judicata between the injured

also A Tanzi, 'Is Damage a Distinct Condition for the Existence of an Internationally Wrongful Act?' in M Spinedi and B Simma (eds), United Nations Codification of State Responsibility (Oceana Publications Inc 1987) 22.

${ }^{121}$ Recent examples of when the ICJ found a declaration of wrongfulness as an appropriate form of reparation in the form of satisfaction include Bosnian Genocide case (n 23) paras 463-4, 469, 471; Certain Questions of Mutual Assistance in Criminal Matters (n 60) paras 203-4; Pulp Mills on the River Uruguay (Argentina v Uruguay) [2010] ICJ Rep 14, para 269; Certain Activities Carried Out by Nicaragua in the Border Area (Costa Rica v Nicaragua) and Construction of a Road in Costa Rica along the San Juan River (Nicaragua v Costa Rica) [2015] ICJ Rep 665, para 229. See also Quiborax SA, Non Metallic Minerals SA and Allan Fosk Kaplún v Plurinational State of Bolivia, ICSID Case No ARB/06/2, Award (16 September 2015) paras 535-6; 550-2; 560-1. See also Armed Activities on the Territory of the Congo (DRC v Uganda) (Reparations owed by the Parties) Counter-memorial of Uganda on Reparation (6 February 2018) para 10.33 .

${ }_{122}$ Corfu Channel Case (UK v Albania) [1949] ICJ Rep 4, 35.

123 Guyana v Suriname (Award) (2007) 30 RIAA 1, paras 445 and 485.

124 Certain Activities Carried Out by Nicaragua in the Border Area (Costa Rica v Nicaragua) and Construction of a Road in Costa Rica along the San Juan River (n 121) paras 96-7.

1252001 ILC Articles (n 3) art 37, Commentary 5: Examples of modalities of satisfaction provided by the ILC include 'due inquiry into the causes of an accident resulting in harm or injury, a trust fund to manage compensation payments in the interests of the beneficiaries, disciplinary or penal action against the individuals whose conduct caused the internationally wrongful act or the award of symbolic damages for non-pecuniary injury.' 
and responsible State. The law of State responsibility is not prescriptive regarding the institutional setting within which it is implemented, and it would go with the grain of this flexibility to treat a determination by the ICC that there has been an act of aggression by a State Party to the Rome Statute, or a non-Party referred by the Security Council, as a possible reparation. Thus, a finding of an act of aggression by the ICC under Article 8 bis(1) may be considered a form of satisfaction, this being the appropriate (and only) remedy available to the aggressor State in this forum. ${ }^{126}$ Moreover, as State responsibility is not forum specific, other forms of reparation may be sought in another forum or, indeed, through the diplomatic invocation of responsibility outside any judicial setting.

As discussed in Section III.C, when determining the State conduct element of the crime of aggression, the Court may make a finding that there has been a use of force which falls short of Article 8 bis(2), or an act of aggression pursuant to Article 8 bis(2) which falls short of the threshold in Article 8 bis(1). Such a finding would also amount to a finding of an internationally wrongful act by the ICC and this could also be considered a form of satisfaction. This would not preclude the injured State from drawing on this finding when seeking other forms of reparation in different fora.

\section{B. Particular Consequences of a Serious Breach of an Obligation Arising from a Peremptory Norm of General International Law}

It is generally accepted that the prohibition of aggression is a peremptory norm of international law. ${ }^{127}$ The definition in Article 8 bis has received attention from the perspective of the law on the use of force, ${ }^{128}$ particularly since the ICC can only consider an act of aggression that satisfies the threshold in paragraph 1 as amounting to the crime of aggression. There appear to be two different standards in Article 8 bis with regard to a breach of an obligation arising from a peremptory norm: a breach (act of aggression) and a more serious breach (which by its character, gravity, and scale, constitutes a manifest violation of the UN Charter). Thus, the threshold in Article 8 bis(1) accords with the nomenclature of the 2001 ILC Articles concerning 'a serious breach of a State of an obligation arising under a peremptory norm of general international law.' ${ }^{129}$ If both are synchronised, a serious breach of a peremptory

\footnotetext{
126 See Bosnian Genocide Case (n 23) para 463.

1272001 ILC Articles (n 3) art 26, Commentary 5; art 40, Commentary 4; ILC Draft Conclusions on Peremptory Norms of General International Law (Jus Cogens) on first reading (n 17) Draft Conclusion 23; D Tladi, 'Fourth Report on peremptory norms of general international law (jus cogens)' (n 17) at 27-9. But see F Paddeu, 'Military Assistance on Request and General Reasons against Force: Consent as a Defence to the Prohibition of Force' (2020) 7 Journal on the Use of Force and International Law 227. $\quad{ }^{128}$ ILA Report on aggression and the use of force (n 17) 28.

1292001 ILC Articles (n 3) art 40. cf D Tladi, 'Third report on peremptory norms of general international law (jus cogens)' (2018) UN Doc A/CN.4/714, Draft Conclusion 21 (refers to a 'breach' of a peremptory norm without further qualification); but see ILC Draft Conclusions on
} 
norm is a necessary condition for individual criminal responsibility for the crime of aggression at the ICC.

An act of aggression which does not constitute a 'manifest violation' of the UN Charter may, perhaps, still be considered a serious breach of a peremptory norm. ${ }^{130}$ But Article 8 bis(1) of the Rome Statute specifically requires a finding of a breach of this intensity for the purposes of attributing conduct to an individual for the crime of aggression. ${ }^{131}$ As Article 40 of the 2001 ILC Articles does not contain any procedure for determining when a serious breach has been committed, ${ }^{132}$ the future practice of the ICC will be particularly relevant. According to Article 41 of the 2001 ILC Articles, two particular obligations are placed on States faced with the commission of a 'serious breach' of obligations arising from a peremptory norm: first, States shall cooperate to bring to an end through lawful means any serious breach; secondly, no State shall recognise as lawful a situation created by a serious breach, nor render aid or assistance in maintaining that situation. ${ }^{133}$ Notably, these consequences apply to States other than the State that has committed the serious breach of a peremptory norm. This regime is known as aggravated State responsibility. ${ }^{134}$

The key difference between the general rules of State responsibility and the regime of aggravated responsibility is that the latter encompasses a multilateral dimension as the rights and obligations of third States are affected. Thus, if the ICC determines that there has been an act of aggression (perhaps even one that falls short of the threshold in Article 8 bis(1) of the Rome Statute), it is also determining that there has been a serious breach of a peremptory norm and,

Peremptory Norms of General International Law (Jus Cogens) on first reading (n 17) Draft Conclusion 19.

${ }^{130}$ In the Jurisdictional Immunities case, with respect to the character of the breach, the ICJ closely paraphrasing Article 41(2) of the 2001 ILC Articles mentioned 'the breach of a jus cogens rule' without further discussion, see Jurisdictional Immunities of the State (Germany $v$ Italy: Greece intervening) [2012] ICJ Rep 99, para 93. See also 2001 ILC Articles (n 3) art 41, Commentary 8 ('[i]t must also be borne in mind that some of the peremptory norms in question, most notably the prohibitions of aggression and genocide, by their very nature require an intentional violation on a large scale.'); Wyler (n 7) 1158, Cassese (n 7) 845-6.

${ }_{131}$ The requirement that individual criminal responsibility for the crime of aggression specifically requires aggravated State responsibility does not appear to be the intention of the drafters with respect to the threshold clause in Article 8 bis of the Rome Statute. Kreß, who participated in the German delegation, outlines three main considerations underlying the drafters' inclusion of the threshold clause in Article 8 bis(1): i) for reasons of consistency vis-à-vis the other crimes under international law in the Rome Statute with respect to the seriousness of the crime; ii) to exclude grey areas of the law on the use of force, iii) to ensure that the definition of the crime of aggression in Article 8 bis of the Rome Statute does not exceed existing customary international criminal law, see Kreß, 'The State Conduct Element' (n 20) 507-10. See also D Costelloe, Legal Consequences of Peremptory Norms in International Law (Cambridge University Press 2017) 190. 1322001 ILC Articles (n 3) art 40, Commentary 9. 133 ibid art 41(1) and (2).

134 G Abi-Saab, 'The Uses of Article 19' (1999) 10 EJIL 339, 349; A Orakhelashvili, Peremptory Norms in International Law (Oxford University Press 2008) 242; N Jorgensen, The Responsibility of States for International Crimes (Oxford University Press 2000) 90; CJ Tams, 'Do Serious Breaches Give Rise to Any Specific Obligations of the Responsible State?' (2002) 13 EJIL 1161, 1161; M Paparinskis, 'The Once and Future Law of State Responsibility' (2020) 114 AJIL 618, 623. 
as such, there are consequences for third States, as set out in Article 41 of the 2001 ILC Articles. Notably, the legal consequences in Article 41 are without prejudice to the other consequences that arise from the breach of the international obligation, ${ }^{135}$ and further consequences which are entailed by a serious breach of a peremptory norm. ${ }^{136}$ In other words, the responsible State is still under an obligation to cease wrongful conduct and make full reparation for the injury caused by the internationally wrongful act, ${ }^{137}$ and international law may provide further consequences for the serious breach of the peremptory norm. ${ }^{138}$ As the ILC Commentary to the 2001 ILC Articles puts it:

international law may recognize additional legal consequences flowing from the commission of a serious breach in the sense of article 40 . The fact that such further consequences are not expressly referred to ... does not prejudice their recognition in present-day international law, or their further development. ... the legal regime of serious breaches is itself in a state of development. By setting out certain basic legal consequences of serious breaches in the sense of article 40 , article 41 does not intend to preclude the future development of a more elaborate regime of consequences entailed by such breaches. ${ }^{139}$

With regard to aggression, additional legal consequences do indeed flow from the commission of a serious breach in the sense of Article 40. Although individual criminal responsibility for aggression exists under customary international law, ${ }^{140}$ and these legal consequences also apply outside the ICC regime; the regime at the ICC for the crime of aggression gives rise to an institutionalised 'elaborate regime' of consequences entailed by a serious breach of a peremptory norm in the sense of Article 40. As the only international forum that can prosecute the crime of aggression, the Rome Statute provides an institutional setting for the determination of a serious breach of a peremptory norm, ${ }^{141}$ upon the finding of which, particular consequences, ie individual criminal responsibility, are entailed. ${ }^{142}$

1352001 ILC Articles (n 3) art 41(3); and as confirmed in the ILC Draft Conclusions on Peremptory Norms of General International Law (Jus Cogens) on first reading (n 17) Draft $\begin{array}{ll}\text { Conclusion 19(4). } & 136 \text { ibid. }\end{array}$

${ }_{138}$ In the case of aggression, the ILC Commentary points to the example of the Security Council as having a specific role under the UN Charter, 2001 ILC Articles (n 3) art 40, Commentary 9.

1392001 ILC Articles (n 3) art 41, Commentary 14.

140 Art 6(a) Charter of the International Military Tribunal (crimes against peace); UNGA Res 95 (1) 1946 (Affirmation of the Principles of International Law recognized by the Charter of the Nuremberg Tribunal); see also M Wong, 'Individual Criminal Responsibility for Violations of Jus Ad Bellum under Customary International Law' in M Bergsmo et al. (eds), Historical Origins of International Criminal Law: Volume 3 (Torkel Opsahl Academic Epublisher 2015); C McDougall, 'The Crimes against Peace Precedent' in C Kreß and S Barriga (eds), The Crime of Aggression: A Commentary (Cambridge University Press 2016) vol I; Kreß, 'The State Conduct Element' (n 20) 510. 141 Rome Statute (n 2) art 8 bis(1). 142 cf Tams, 'Do Serious Breaches Give Rise to Any Specific Obligations of the Responsible State?' (n 135) 1173-8. 
V. THE IMPLEMENTATION OF STATE RESPONSIBILITY FOR AN ACT OF AGGRESSION

AND THE ICC

State responsibility, and the content of responsibility arise independently of invocation by another State. ${ }^{143}$ The injured State is not the only State with a legal interest in the invocation of State responsibility for aggression. The primary obligation under international law concerning the prohibition of aggression is of an erga omnes character, ${ }^{144}$ which means that the obligation is also owed to the international community as a whole. ${ }^{145}$ Thus, every State has a legal interest in compliance with the obligation prohibiting aggression, ${ }^{146}$ and may invoke the responsibility of an alleged aggressor State, ${ }^{147}$ even if they individually have not been injured by the breach. ${ }^{148}$

As discussed in Section IV, the findings of the ICC may amount to reparation in the form of satisfaction. This section will consider the avenues available at the ICC for States Parties entitled to invoke the responsibility of an aggressor State (Party). Could States Parties entitled to invoke the responsibility of an aggressor State rely on the available trigger mechanisms to initiate proceedings? This section will first consider the invocation of responsibility by the victim State of the alleged aggressor State, and then consider the invocation of responsibility based on the erga omnes nature of the primary obligation.

\section{A. The Invocation of Responsibility by an Injured State Party}

Part Three of the 2001 ILC Articles provides the general framework for the implementation of State responsibility. The most obvious actor to consider for invocation of responsibility is the injured State. ${ }^{149}$ Article 42 of the 2001 ILC Articles stipulates that an injured State is entitled to invoke the responsibility of another State if the obligation breached is owed to that State. ${ }^{150}$ An injured State that is party to the Rome Statute may refer a situation to the Prosecutor under Article 15 bis of the Rome Statute to initiate an investigation of the crime of aggression, and so this is one of the avenues available to an injured State that is a party to the Rome Statute to invoke the responsibility of the aggressor State (Party). A State referral by the injured

1432001 ILC Articles (n 3) Part Three, Commentary.

144 The ICJ named the outlawing of aggression as an example of an obligation erga omnes in Barcelona Traction (n 18) para 34. See also Tanzi (n 120) 31; J Crawford, 'Responsibility for Breaches of Communitarian Norms: An Appraisal of Article 48 of the ILC Articles on Responsibility of States for Internationally Wrongful Acts' in U Fastenrath et al. (eds), From Bilateralism to Community Interest: Essays in Honour of Bruno Simma (Oxford University Press 2011) 228-39. $\quad 1452001$ ILC Articles (n 3) art 33. $\quad 146$ ibid arts 42(b) and 48.

147 I Scobbie, 'The Invocation of Responsibility for the Breach of "Obligations under Peremptory Norms of General International Law"' (2002) 13 EJIL 1201, 1207-8; Crawford, 'Responsibility for Breaches of Communitarian Norms: An Appraisal of Article 48 of the ILC Articles on Responsibility of States for Internationally Wrongful Acts' (n 144) 228-39.

${ }^{148}$ In the pending Myanmar Genocide case (n 118) para 41; Sicilianos (n 19) 1139-40; Scobbie (n 147) 1213-15. $\quad 149$ Sicilianos (n 19) $1139 . \quad{ }^{150} 2001$ ILC Articles (n 3) art 41. 
State (Party) under Article 15 bis can be understood as a form of invocation of responsibility for an act of aggression or, at the very least, a lex specialis mechanism that is functionally analogous to and builds upon the customary rule. It is worth recalling that, as a general matter, the law of State responsibility is open to the possibility of lex specialis mechanisms that partially modify customary rules and adapt them to particular institutional settings, including by third-party decision-makers, as has been done by the World Trade Organization with regard to countermeasures. ${ }^{151}$ The procedural mechanisms of the ICC may be seen as consonant with this institutional practice.

The 2001 ILC Articles do not say how notice should be given, or the forms of invocation, and there appears to be great flexibility in this regard. ${ }^{152}$ In addition, States may choose between the various forms of reparation. ${ }^{153}$ This may be of relevance when the State wishing to refer a situation to the Prosecutor pursuant to Article 15 bis takes into account the requirement to provide notice to the alleged aggressor State of which the perpetrator is a national.

\section{B. The Invocation of Responsibility by States other than an Injured State and International Organisations}

States other than an injured State, as members of the international community, have a legal interest in the compliance with an obligation erga omnes. ${ }^{154}$ Article $48(1)$ of the 2001 ILC Articles stipulates that a State other than an injured State is entitled to invoke the responsibility of another State if the obligation breached is owed to the international community as a whole. The important caveat is that, under Article 48, a claim for the performance of the obligation of reparation can only be invoked in the interest of the injured State or of the beneficiaries of the obligation breached. ${ }^{155}$ As shown in Section IV A, in the context of aggression, the proceedings before the ICC can result in penal sanctions against an

151 ibid Part Three, Ch II, Commentary 9, and art 50, Commentary 10.

1522001 ILC Articles (n 3) art 43, Commentary 4; relevant examples include Democratic Republic of Congo (DRC) invoking the responsibility of Uganda for acts of aggression perpetrated by Uganda on the territory of the DRC, in flagrant violation of the UN Charter and of the Charter of the Organization of African Unity, Armed Activities on the Territory of the Congo (n 98) paras 175-9. See also the Application Instituting Proceedings filed in the Registry of the Court on 23 June 1999, and Ethiopia invoking the responsibility of Eritrea for loss, damage and injury suffered by the Claimant, including loss, damage and injury suffered by its nationals, as a result of the alleged use of force against the Claimant in violation of the rules of international law on resorting to the use of force, Eritrea-Ethiopia Claims Commission-Partial Award (n 97) 457-69.

${ }^{153}$ In the Obligations concerning Negotiations relating to Cessation of the Nuclear Arms Race and to Nuclear Disarmament case, the Court was sceptical about an overly formalistic reading of the notice requirement and its application in judicial settings, Obligations concerning Negotiations relating to Cessation of the Nuclear Arms Race and to Nuclear Disarmament (Marshall Islands v UK) (Preliminary Objections) [2016] ICJ Rep 833, para 45. See 2001 ILC Articles (n 3) art 43. Commentary 4.

1552001 ILC Articles (n 3) art 48(2). 
individual and determination that there has been an act of aggression pursuant to Article 8 bis of the Rome Statute. Understanding satisfaction as an extraordinary reparation available at the ICC for aggression accords with Article 48 of the ILC Articles. ${ }^{156}$

Thus, a State other than the injured State, and which is a party to the Rome Statute, may refer a situation pursuant to Article 15 bis of the Rome Statute. Additionally, a State other than an injured State, which is not a party to the Rome Statute, may submit a communication to the OTP in view of the exercise of proprio motu powers pursuant to Article 15 bis. Thus, Article 15 bis of the Rome Statute seems analogous to Article 48 of the 2001 ILC Articles, in that a State other than an injured State may refer a situation to the Prosecutor with regard to the crime of aggression, arising from an act of aggression by a State Party, or submit a communication regarding a situation to the OTP in light of proprio motu powers. Notably, the rules pertaining to the notice of a claim pursuant to Article 48 are the same as those for Article 42 as examined above. ${ }^{157}$

Article 15 ter of the Rome Statute provides for the UN Security Council to make a referral, acting as a trigger mechanism for the initiation of an investigation concerning a crime of aggression ${ }^{158}$, as does Article 15 bis which permits the Prosecutor to initiate an investigation proprio motu. In such cases, it is the OTP and Security Council ${ }^{159}$, as organs of International Organisations, which act in furthering the interests of the international community. The ICC and Security Council are, of course, not States for the purposes of invocation of responsibility under Article 48 of the 2001 ILC Articles. Articles 15 bis and 15 ter of the Rome Statute could be seen as providing an institutionalised response to a serious breach of a peremptory norm for the purposes of Article 40 of the 2001 ILC Articles, ${ }^{160}$ that is, enabling the OTP (ICC) and the Security Council (UN) to trigger the process for the invocation of international responsibility for aggression (of the State and individual).

Although the ICC is not a part of the UN institutional framework as such, ${ }^{161}$ the Rome Statute does expressly allow the Security Council to trigger the initiation of an investigation under Chapter VII of the UN Charter. ${ }^{162}$ There is clearly a relationship between the ICC and the UN, ${ }^{163}$ particularly in the case of (the crime of) aggression, ${ }^{164}$ and in which, the Security Council has a

156 CJ Tams, 'Individual States as Guardians of Community Interests' in U Fastenrath et al. (eds), From Bilateralism to Community Interest: Essays in Honour of Bruno Simma (Oxford University Press 2011).

157 A Gattini, 'A Return Ticket to “Communitarisme”, Please' (2002) 13 EJIL 1181, 1196.

158 See Klein (n 7) 1243-7.

159 Tanzi (n 120) 32; Cassese (n 7) 846; Klein (n 7) 1248-50. $\quad{ }^{160}$ Klein (n 7) 1250-5.

161 For a study on the implementation of State responsibility by UN Organs, see V-J Proulx, Institutionalizing State Responsibility: Global Security and UN Organs (Oxford University Press 2016). 162 Rome Statute (n 2) art 13(b).

164 ibid former art 5(2). See also Blokker (n 49). 
specific role. ${ }^{165}$ This seems to reflect Article 41(3) of the 2001 ILC Articles, as being 'further consequences' that a 'serious' breach (for the purposes of Article 40) may entail under international law. ${ }^{166}$

\section{Further Implications}

What further implications may arise on the inter-State level from the Court's finding of an act of aggression? The question of whether such a finding has the force of res judicata is beyond the scope of this article, but three tentative points will be made.

First, even if the determination is not treated as technically binding in another (inter-State) forum, the finding by the Court that an act of aggression has occurred carries great weight as a subsidiary means for determining rules of international law. ${ }^{167}$ In the field of international courts and tribunals, one analogy may be provided by advisory opinions of the ICJ, not binding as such but capable of authoritatively explaining the content of binding rules, including on issues of State responsibility. ${ }^{168}$ Moreover, international legal process uses advisory opinions as one important step for authoritatively determining legal position, which the political organ of international organisations can take as the starting point for further action, again in line with the desirable effects of ICC work on aggression. ${ }^{169}$

Secondly, a determination of an act of aggression pursuant to Article 8 bis is a legal finding by the Court that there has been an internationally wrongful act. It is important as a formal identification by an international court of a breach of international law, weighing and evaluating legal and factual claims in a judicial forum. Recall, however, that legal consequences under law of State

\footnotetext{
1652001 ILC Articles (n 3) art 40, Commentary 9, and art 41, Commentary 14; see also Cassese (n 7$) 846$.

167 Art 38(1)(d) Statute of the International Court of Justice.

168 For example, Chagos (n 93) paras 177-82. Legal findings by international criminal tribunals on issues of international law, including responsibility, have been given considerable weight by the International Court of Justice, Bosnian Genocide (n 23) paras 190, 195, 198-201, 292, 296, 300; The treatment of an ICJ advisory opinion in the recent judgment of the International Tribunal for the Law of the Sea in Mauritius/Maldives is one example of the importance that international law attributes to judicial determinations of State responsibility, whether or not they are binding on the States concerned, Dispute concerning delimitation of the maritime boundary between Mauritius and Maldives in the Indian Ocean (Mauritius/Maldives) (Preliminary Objections of the Republic of Maldives, 18 December 2019) ITLOS Reports 2021, paras 140-251.

169 UNGA Res 71/292, 'Request for an advisory opinion of the International Court of Justice on the legal consequences of the separation of the Chagos Archipelago from Mauritius in 1965' (22 June 2017) UN Doc A/RES/71/292; UNGA Res 73/295, 'Advisory opinion of the International Court of Justice on the legal consequences of the separation of the Chagos Archipelago from Mauritius in 1965' (22 May 2019) UN Doc A/RES/73/295; UNGA Special Political and Decolonization Committee (Fourth Committee), Summary record of the 7 th meeting (9 December 2019) UN Doc A/C.4/74/SR.7; see also UN Press release, 'Delegates call upon United Kingdom to Comply with Ruling by International Court of Justice that Chagos Archipelago's decolonization was never lawfully completed' (UN.org, 15 October 2019) <https://www.un.org/ press/en/2019/gaspd696.doc.htm>.
} 
responsibility do not stem from invocation or determination but from the breach. It is the breach that creates a new legal relationship whereby the wrongdoing (aggressor) State has an obligation to cease wrongful conduct and make full reparation for the injury caused by aggression to the extent that it has not been achieved by satisfaction, including by restitution and compensation.

Thirdly, whilst it may be objected that the ICC cannot provide a forum in which full reparation for the injury caused by the aggression can be awarded, the decentralised system of international law means that it is not unusual for there to be no formal settings in which the responsibility of a State may be invoked by another State under Article 42 or 48 of the 2001 ILC Articles. The content of State responsibility still applies, even in the absence of a forum: 'in the (still) sparsely judicialised international law, State responsibility is conceptually autonomous of particular (or indeed any) judicial institutions for implementation'. ${ }^{170}$ One may be dispirited by the seeming insignificance of a finding that a State is responsible for an act of aggression in a judicial forum unable to award full reparations. However, this is the reality of legal process in the international legal system. When considered from that perspective, the specialised institutional regime at the ICC represents a significant development in international law, as the Court provides a formal judicial setting which has the competence, at least partially, to identify the responsibility of States for acts of aggression.

\section{CONCLUDING REMARKS}

Aggression at the ICC has been extensively considered from the perspective of international criminal law and procedure. This article has sought to do so from the perspective of the law of State responsibility, connecting the threads between an important specialised field of international law and its foundational elements. The content of State responsibility arises from the internationally wrongful act of aggression, independently of any invocation by a State entitled to do so under Articles 42 and 48 of the 2001 ILC Articles. That said, the ICC provides an institutional setting in which such States may trigger a process through which international responsibility (of the State and individual) for aggression may be determined. Although legal consequences arise independently of invocation and determination of responsibility, the Court's judicial finding may serve as a form of satisfaction, amounting to a form of reparation for the act of aggression under the law of State responsibility.

The law of State responsibility also recognises an aggravated regime, arising from a serious breach of a jus cogens obligation. Aggression for the purposes of

${ }^{170}$ M Paparinskis, 'A Case Against Crippling Compensation in International Law of State Responsibility’ (2020) 83 MLR 1246, 1251. 
the crime of aggression in Article 8 bis(1) of the Rome Statute clearly comprises a serious breach of a peremptory norm as its character, gravity and scale, constitutes a manifest violation of the UN Charter. The ICC provides an institutionalised setting competent to determine whether such a serious breach of a peremptory norm has occurred. This is a significant development in international law, and has implications both for situating the ICC within the broader international legal order and for reflecting on the role of international organisations with regard to aggravated responsibility. 